\title{
Influence of Working Capital Management on Profitability: A Study on Indian FMCG Companies
}

\author{
Bhaskar Bagchi ${ }^{1}$, Jayanta Chakrabarti ${ }^{2}$ \& Piyal Basu Roy ${ }^{3}$ \\ ${ }^{1}$ Department of Commerce, Alipurduar College, Jalpaiguri, West Bengal, India \\ ${ }^{2}$ Department of Economics, Alipurduar College, Jalpaiguri, West Bengal, India \\ ${ }^{3}$ Department of Geography, Alipurduar College, Jalpaiguri, West Bengal, India \\ Correspondence: Bhaskar Bagchi, Department of Commerce, Alipurduar College, Dist. Jalpaiguri, Pin 736122, \\ West Bengal, India. Tel: 91-947-707-3143. E-mail: bagchi_bhaskar@yahoo.in
}

Received: July 21, 2012 Accepted: September 14, 2012 Online Published: October 18, 2012

doi:10.5539/ijbm.v7n22p1 URL: http://dx.doi.org/10.5539/ijbm.v7n22p1

\begin{abstract}
The paper aims to explore the effects of components of working capital management like cash conversion cycle (CCC), age of inventory (AI), age of debtors (AD), age of creditors (AC), debt to total assets (DTA) and debt equity ratio (DER) on profitability of FMCG firms. The profitability of firms is measured in terms of return on total assets (ROTA) and return on investment (ROI). Working capital management is considered to be a vital issue in financial management decision and it affects both liquidity and profitability of the firm. The secondary data for analysis is retrieved from Prowess Database of CMIE for ten year period from 2000-01 to 2009-10. Apart from using Pearson's correlation analysis, panel data regression analysis like pooled OLS model and fixed effect LSDV model are employed in the study. Like previous authors, our study results show a sturdy negative association between working capital management variables and firms' profitability. The results of our study also indicate the better explanatory power of fixed effect LSDV model than that of pooled OLS model.
\end{abstract}

Keywords: FMCG, working capital management, profitability, fixed effect LSDV, pooled OLS

\section{Introduction}

The FMCG industry has emerged as one of the largest sectors in the Indian economy by registering an astonishing double-digit growth rate in sales in the past couple of years. Characterized by healthy distribution network, strong MNC presence, tough rivalry between the structured and the unstructured segments and low operational costs, it is one of the rapid growing industries in India with a total market size US \$13.1 billion (CMIE, 2011).

Working capital management is considered to be a vital issue in a firm's overall financial management. Working capital management has both liquidity and profitability insinuations. Favorable working capital management can be achieved by the finance manager of a firm, by trading off between liquidity and profitability in a precise way. It is learnt, that finest management of working capital positively contributes in creating firms' value.

The decisive element in management of working capital necessitates, maintaining firms' liquidity management in daily maneuver to guarantee its soft running and meeting its obligation (Eljelly, 2004). A study of working capital management is of foremost significance for financial analysts on account of its intimate association with day by day operations of a firm. Quandary in managing liquidity is to attain preferred swapping between liquidity and profitability (Raheman \& Nasr, 2007). However, with reference to the principle of risk and return, investment that is associated with more risk will obviously produce higher yield. Therefore, the firms that sustain liquidity and working capital at higher level will certainly have low operational risk, which in turn also results in lower profitability. On the contrary, the firms that keep its liquidity and working capital at lesser level are being confronted with elevated risk and also lofty returns. Therefore, in optimal management of working capital, the firms should take into deliberation all the components of liquidity as well as working capital and attempt to equilibrium the risk and return (Lee et. al., 2008).

Firms have to maintain the working capital management in a most favorable way which can maximize its value. Huge inventory base and a liberal trade credit policy may lead to lofty sales, whereas huge inventory in hand, lessen the chance of a stock-out. On the other hand, trade credit may boost-up sales of a firm, as it permits the 
clientele to judge the excellence of the products prior to payment (Long et. al., 1993, and Deloof \& Jegers, 1996) One of the well-accepted measures of working capital is the cash conversion cycle (CCC), which is defined as the time gap in the midst of the disbursement made for the procurement of raw materials and the assortment of sales of finished goods. Therefore, the lengthier is this time gap, the bigger is the investment in working capital (Deloof 2003). Occasionally, lengthier cash conversion cycle may raise profitability of the firm, since it guides to elevated sales. Nevertheless, if the expenditure of elevated investment in working capital increases quicker than the advantages of keeping added inventories and/or conceding further trade credit to the clientele, the firms' profitability may goes down with the cash conversion cycle (Raheman \& Nasr, 2007).

Extensive empirical research on working capital management was carried out worldwide by the academia in order to hypothesize firms' performance (Agarwal, 1988; Shin \& Soenen, 1998; Deloof, 2003; Lazaridis \& Tryfonidis, 2006; Padachi, 2006; Ganesan, 2007; Raheman \& Nasr, 2007; Christopher \& Kamalavalli, 2009; Uyar, 2009 and many others). Even so, the effect of various working capital mechanisms on firm's performance from Indian FMCG perspective might be vaguely different due to the divergence in business environment from other countries. Considering the impending contribution of working capital management on firm performance which is ultimately related to the economy of India, therefore, the objective of our study is to discover the relationships between working capital management and profitability in a sample of Indian FMCG companies from a new dimension.

This study is an extension of our earlier study (Bagchi \& Khamrui, 2012) in a sense that it examines the impact of working capital management on two important indicators of profitability, return on total assets and return on investment. Moreover, this study attempts to overcome the drawbacks of pooled OLS regression model used in our previous study, by employing fixed effect least-squares dummy variables (LSDV) model that allows for heterogeneity among subjects by allocating each FMCG firms to have its own intercept value.

\section{Survey of Literature}

The magnitude of working capital management has been examined by different authors and the review of prior literature reveals that there subsists a significant relationship between firms' performance and working capital management by using different selected variable for analysis.

Deloof (2003) is of the opinion that the majority of the firms had invested a large amount of cash in working capital and it is anticipated that the management of working capital of the firms would notably affect the profitability. He established a noteworthy negative relationship between gross operating income and the number of days accounts receivable, inventories and accounts payable in the case of Belgian firms with the help of correlation and regression analysis. The findings of the his study recommended that by plummeting the number of days' accounts receivable and inventories, the finance managers can generate worth for their shareholders. On the contrary, the negative affiliation between accounts payable and firms' profitability supports the hypothesis that firms with lesser profits take longer time to pay off their creditors.

Padachi (2006) had undertaken a study with the objective of examining the effect of accounts receivables days, inventories days, accounts payable days and cash conversion cycle on return on total assets. He also analyses the tendency in working capital requirements of firms, for a sample of 58 small manufacturing firms in Mauritius for the period 1998 -2003. Using pooled OLS and fixed effect regression model, he established that lower profitability was related with higher investment in receivables and inventories. The findings also reveal a rising tendency in the short-term component of financing working capital.

Ganesan (2007) analysed the efficiency of firms' working capital management using a sample of telecommunication equipment companies. The variables used to represent the working capital were days' sales outstanding, days' inventory outstanding, days' payable outstanding, days' working capital, and current ratio while, profitability and liquidity were represented by cash conversion efficiency, income to total assets and income to sales. The findings of the study support the substantiation that although days' working capital was negatively associated with the profitability, yet, it was unable to influence the profitability of the firms in a significant manner.

Garcia-Teruel and Martinez-Solano (2007) evaluated the impact of working capital management on firms' profitability using a sample of Spanish SMEs. The findings of their study show that the finance managers were capable of generating firms' value by dipping their inventories along with the age of debtors. In addition, the firm's profitability could be also improved by reducing the cash conversion cycle.

Mathuva (2009) investigated the impact of the components of working capital management upon profitability of the firms. His sample consists of 30 listed firms from Nairobi Stock Exchange (NSE) and the period of his study 
ranges from 1992-93 to 2007-08. Apart from using Pearson's correlations and Spearman's correlations, panel data regression analysis like pooled OLS and fixed effects models (FEM) were also employed in the study. He found negative relationship between the age of debtors and profitability while, a positive association was originated between the inventory conversion period and profitability, and also between age of creditors and profitability of the selected firms.

Ching, Novazzi and Gerab (2011) conducted a study to find out the relationship between working capital management and profitability in Brazilian listed companies. The objectives of their study were to investigate if there was any difference between corporate profitability and working capital management in two separate groups of companies: working capital intensive and fixed capital intensive; and to identify the variables that most affect profitability. They have measured profitability in three different ways: return on sales (ROS), on asset (ROA) and return on equity (ROE). The independent variables used are cash conversion efficiency, debt ratio, days of working capital, days' receivable and days' inventory. Multiple linear regression used in their study identified that, there exists negative relationship between cash conversion cycle (equal to days of working capital), debt ratio and profitability.

All the above literature that has been surveyed not only gives us a firm support and thoughtful idea in conducting the working capital analysis but, additionally provides the findings and conclusions of their study on working capital management in the perspective of various countries and different industries across the globe. Therefore, keeping in mind the mechanisms of the researches conducted in different business environment, our research methodology for this present study has been developed.

\section{Research Questions}

To gain an insight and understand the relationship, between working capital management and profitability in Indian context for a sample of 10 Indian FMCG companies over a period of 10 years (2000-01 to 2009-10), we seek answers to the following questions which are addressed below:

- What is the nature and extent of the relationship between working capital management, solvency and profitability? and

- How different components of working capital management jointly affect profitability?

\section{Methodology}

The principal endeavor of this paper is to explore the impact of working capital management on corporate profitability of Indian FMCG firms. To achieve this, we have developed an empirical framework which was first used by Shin and Soenen (1998), Deloof (2003) and subsequently by Padachi (2006) and Mathuva (2009). But, unlike these studies we have analysed the joint impact of working capital management on return on total assets and also return on investment. Furthermore, we have also taken into account the individuality or uniqueness of each selected FMCG firms and allow each firm to have its own individual regression coefficient so that the heterogeneous characteristics that may exist among FMCG firms are not being camouflaged or individuality of each subject is not subsumed in the disturbance term $\varepsilon_{\mathrm{it}}$.

\subsection{Data Set \& Sample Design}

The data used in the present study was acquired from CMIE database. The purposive sample design method was applied in this analysis. Preferred samples of 10 FMCG companies from the year of 2000-2001 to 2009-2010 were utilized in this analysis. The sample size is restricted to only 10 FMCG firms because latest data for analysis was available from CMIE database for these 10 FMCG firms only. Using chosen sample of firms, may perhaps initiate discrimination in the accomplishment of a selected firm. There is an assertion, that the probability for firms' achievement may be ostentatious if this method is used. Nevertheless, there is an argument that the importance of the biasness in selection of firms depends on how the model is being used. For example, if the model is applied in ranking the firms intended for possible accomplishment in executing further thorough investigation, in that case the discrimination is not considered to be a vital one. Conversely, if the model is being applied in selection of investment group, at that moment the partiality or biasness will be important. (Bhunia, 2011).

\subsection{Measurement of Variables}

Selection of variables is influenced by the earlier studies on working capital management undertaken by different authors as mentioned earlier in this paper. The variables which are mentioned hereunder in table 1 have been used to achieve the objectives of our study. The efficiency ratios namely age of inventory (AI), age of debtors (AD) and age of creditors (AC), solvency ratios like debt-equity ratio (DER), financial stability ratio like debt to total assets (DTA) and cash conversion cycle (CCC) are taken as explanatory variables. Cash Conversion Cycle 
(CCC) is utilized as an inclusive determination of working capital, because it explains the time gap in the midst of the disbursement made for the procurement of raw materials and the assortment of sales of finished goods. Therefore, the lengthier is this time gap, the bigger is the investment blocked in working capital. The explained variables, return on total assets and return on investment are defined as the profitability of the sample firms. All the above selected variables have been computed as follows:

Table 1. Measurement of selected variables

\begin{tabular}{ll}
\hline \multicolumn{1}{c}{ Variables } & \multicolumn{1}{c}{ Method of Computation } \\
\hline Cash conversion Cycle (CCC) & (No. of Days Accounts Receivables + No. of Days Inventory) - No. of \\
& Days Accounts Payable \\
Debt to Total Assets (DTA) & External Equities or debts / Total assets \\
Debt-Equity Ratio (DER) & External Equities or debts/Equity capital \\
Age of Inventory (AI) & (Average Inventory/Average Cost of Sales) x 365 days \\
Age of Debtors (AD) & (Average Debtors/Average Annual Credit Sales) x 365 days \\
Age of Creditors (AC) & (Average Creditors/Average Cost of Sales) x 365 days \\
Return on Total Assets (ROTA) & PBIT/ Total assets \\
Return on Investment (ROI) & PBIT/Capital Employed \\
\hline
\end{tabular}

\subsection{Empirical Models}

In order to test our proposition, panel data regression analysis of cross-sectional and time series data have been employed in the study. We have used pooled OLS model and fixed effects least-squares dummy variable (LSDV) model. In pooled OLS model we simply pool all 100 observations and estimate a 'grand' regression, neglecting the cross-sectional and time series nature of our data with an assumption that there is no major cross-sectional or temporal effect. That is, there is no distinction between the FMCG firms - one FMCG firm is as good as the other, irrespective of their size. This is considered to be the major problem with this model that it does not distinguish between various firms. However, in order to overcome this weakness we have employed fixed effects least-squares dummy variable model where we also pool all 100 observations, but allow each cross-sectional unit (i.e. FMCG firms in our case) to have its own (intercept) dummy variables. Under these circumstances, the following regression models are tested:

$$
\begin{gathered}
\text { ROTA }_{i t}=\beta_{1 \mathrm{i}}+\beta_{2} \mathrm{CCC}_{\text {it }}+\beta_{3} \mathrm{DTA}_{\mathrm{it}}+\beta_{4} \mathrm{DER}_{\mathrm{it}}+\beta_{5} \mathrm{AI}_{\mathrm{it}}+\beta_{6} \mathrm{AD}_{\mathrm{it}}+\beta_{7} \mathrm{AC}_{\mathrm{it}}+\varepsilon_{\mathrm{it}} \\
\mathrm{ROI}_{\mathrm{it}}=\beta_{1 \mathrm{i}}+\beta_{2} \mathrm{CCC}_{\mathrm{it}}+\beta_{3} \mathrm{DTA}_{\mathrm{it}}+\beta_{4} \mathrm{DER}_{\mathrm{it}}+\beta_{5} \mathrm{AI}_{\mathrm{it}}+\beta_{6} \mathrm{AD}_{\mathrm{it}}+\beta_{7} \mathrm{AC}_{\mathrm{it}}+\varepsilon_{\mathrm{it}}
\end{gathered}
$$

where:

ROTA $_{\text {it }}=$ Return on Total Asset counted yearly of each firm; $\mathrm{ROI}_{\mathrm{it}}=$ Return on Investment counted yearly of each firm; $\mathrm{CCC}_{\mathrm{it}}=$ Cash Conversion Cycle counted yearly of each firm; $\mathrm{DTA}_{\mathrm{it}}=$ Debt to Total Asset Ratio counted yearly of each firm; $\mathrm{DER}_{\mathrm{it}}=$ Debt-Equity Ratio counted yearly of each firm; $\mathrm{AI}_{\mathrm{it}}=$ Age of Inventory counted yearly of each firm; $\mathrm{AD}_{\mathrm{it}}=\mathrm{Age}$ of Debtors counted yearly of each firm; $\mathrm{AC}_{\mathrm{it}}=\mathrm{Age}$ of Creditors counted yearly of each firm.

In the above models, it is to note that we have put the subscript $i$ on the intercept term $\beta_{1}$ to suggest that the intercepts of the 10 FMCG firms may be different. The difference may be due to special features of each firm, i.e. managerial style, managerial philosophy, range of products or the type of market each firm is serving. Although, the intercept may differ across 10 FMCG firms, each entity's intercept does not vary over time, i.e. it is time-invariant. Now, in order to allow the intercept to vary among the FMCG firms using the dummy variable technique, particularly the differential intercept dummy technique, we rewrite equations 1 and 2 as:

$$
\begin{gathered}
\text { ROTA }_{\text {it }}=\alpha_{1}+\alpha_{2} \mathrm{D}_{2 \mathrm{i}}+\alpha_{3} \mathrm{D}_{3 \mathrm{i}}+\alpha_{4} \mathrm{D}_{4 \mathrm{i}}+\alpha_{5} \mathrm{D}_{5 \mathrm{i}}+\alpha_{6} \mathrm{D}_{6 \mathrm{i}}+\alpha_{7} \mathrm{D}_{7 \mathrm{i}}+\alpha_{8} \mathrm{D}_{8 \mathrm{i}}+\alpha_{9} \mathrm{D}_{9 \mathrm{i}}+\alpha_{10} \mathrm{D}_{10 \mathrm{i}}+\beta_{2} \mathrm{CCC}_{\mathrm{it}}+\beta_{3} \mathrm{DTA}_{\mathrm{it}}+ \\
\beta_{4} \mathrm{DER}_{\mathrm{it}}+\beta_{5} \mathrm{AI}_{\mathrm{it}}+\beta_{6} \mathrm{AD}_{\mathrm{it}}+\beta_{7} \mathrm{AC}_{\mathrm{it}}+\varepsilon_{\mathrm{it}} \\
\mathrm{ROI}_{\mathrm{it}}=\alpha_{1}+\alpha_{2} \mathrm{D}_{2 \mathrm{i}}+\alpha_{3} \mathrm{D}_{3 \mathrm{i}}+\alpha_{4} \mathrm{D}_{4 \mathrm{i}}+\alpha_{5} \mathrm{D}_{5 \mathrm{i}}+\alpha_{6} \mathrm{D}_{6 \mathrm{i}}+\alpha_{7} \mathrm{D}_{7 \mathrm{i}}+\alpha_{8} \mathrm{D}_{8 \mathrm{i}}+\alpha_{9} \mathrm{D}_{9 \mathrm{i}}+\alpha_{10} \mathrm{D}_{10 \mathrm{i}}+\beta_{2} \mathrm{CCC}_{\mathrm{it}}+\beta_{3} \mathrm{DTA}_{\mathrm{it}}+\beta_{4} \mathrm{DER}_{\mathrm{it}}+ \\
\beta_{5} \mathrm{AI}_{\mathrm{it}}+\beta_{6} \mathrm{AD}_{\mathrm{it}}+\beta_{7} \mathrm{AC}_{\mathrm{it}}+\varepsilon_{\mathrm{it}}
\end{gathered}
$$

where: 
$\mathrm{D}_{2 \mathrm{i}}=1$ for FMCG firm 2, 0 otherwise; $\mathrm{D}_{3 \mathrm{i}}=1$ for FMCG firm 3, 0 otherwise; $\mathrm{D}_{4 \mathrm{i}}=1$ for FMCG firm 4, 0 otherwise; $\mathrm{D}_{5 \mathrm{i}}=1$ for FMCG firm 5, 0 otherwise; $\mathrm{D}_{6 \mathrm{i}}=1$ for FMCG firm 6, 0 otherwise; $\mathrm{D}_{7 \mathrm{i}}=1$ for FMCG firm 7, 0 otherwise; $\mathrm{D}_{8 \mathrm{i}}=1$ for FMCG firm 8, 0 otherwise; $\mathrm{D}_{9 \mathrm{i}}=1$ for FMCG firm 9, 0 otherwise; and $\mathrm{D}_{10 \mathrm{i}}=1$ for FMCG firm 10, 0 otherwise.

Since, we have 10 FMCG firms, we have introduced only 9 dummy variables to avoid dummy-variable trap or the situation of perfect collinearity. Here we are treating FMCG firm 1 as the base or reference category. As a result, the intercept $\alpha_{1}$ is the intercept value for FMCG firm 1 and the other $\alpha$ differential intercept coefficients represent by how much the intercept values of other FMCG firms differ from the intercept value of the FMCG firm 1.

\section{Empirical Analysis}

\subsection{Test of Normality}

Shapiro-Wilks' test and Lilliefors test, are the two most common normality tests, that are being used for testing normality of a series of data. Amongst the two, Shapiro-Wilks' test is considered to be a better one into several statistical situation compared to other tools that are used for testing normality. Besides, this test is compatible for small sample size. If the values of the Kolgomorov Smirnov D statistics are high, in that case the null hypothesis will be discarded. According to Norušis (1993), "it is almost impossible to find data that are exactly normally distributed".

Table 2 below, reveal the values of Kolgomorov Smirnov tests (altered for Lilliefors) and Shapiro-Wilks' test. It has been found that under Shapiro-Wilks' test, 7 variables are statistically significant at either $1 \%$, or at $5 \%$ or at $10 \%$ level. On the contrary, under Kolgomorov Smirnov tests, 5 variables are found to be statistically significant at either $1 \%$, or at $5 \%$ level. Therefore, in this situation the null hypothesis is eliminated.

Table 2. Normality tests for all variables (10 FMCG firms, 2000-01 to 2009-10: 100 firm-year observations)

\begin{tabular}{clllcccc}
\hline \multirow{2}{*}{ Variables } & \multicolumn{2}{c}{ Details } & \multicolumn{2}{c}{ Shape } & \multicolumn{2}{c}{ Kolmogorov-Smirnov $^{\mathrm{a}}$} & \multicolumn{2}{c}{ Shapiro-Wilks' } \\
\cline { 3 - 7 } & & Skewness & Kurtosis & Stat. & Sig & Stat. & Sig \\
\hline 1 & Cash conversion Cycle $\left(\mathrm{CCC}_{\mathrm{it}}\right)$ & 0.353 & -0.114 & 0.075 & 0.183 & 0.985 & 0.317 \\
2 & Debt-Equity Ratio $\left(\mathrm{DER}_{\mathrm{it}}\right)$ & 1.575 & 2.467 & 0.197 & 0.000 & 0.823 & 0.000 \\
3 & Debt toTotal Assets Ratio $\left(\mathrm{DTA}_{\mathrm{it}}\right)$ & 1.782 & 3.232 & 0.191 & 0.000 & 0.814 & 0.000 \\
4 & Age of Debtors $\left(\mathrm{AD}_{\mathrm{it}}\right)$ & -0.378 & -0.548 & 0.115 & 0.002 & 0.966 & 0.011 \\
5 & Age of Creditors $\left(\mathrm{AC}_{\mathrm{it}}\right)$ & -0.046 & -0.722 & 0.080 & 0.119 & 0.977 & 0.071 \\
6 & Age of Inventory $\left(\mathrm{AI}_{\mathrm{it}}\right)$ & 0.443 & -0.586 & 0.113 & 0.003 & 0.958 & 0.003 \\
7 & Return on Total Assets $\left(\mathrm{ROTA}_{\mathrm{it}}\right)$ & -0.383 & 0.490 & 0.074 & 0.192 & 0.978 & 0.092 \\
8 & Return on Investment $\left(\mathrm{ROI}_{\mathrm{it}}\right)$ & 0.140 & -0.428 & 0.097 & 0.021 & 0.972 & 0.031 \\
\hline
\end{tabular}

* This is a lower bound of the true significance

a. Lilliefors Significance Correction

\subsection{Correlation Statistics}

Correlation coefficient is computed from selected working capital management and profitability ratios obtained from ten year financial statements of the selected quoted companies.

\subsubsection{Pearson's Correlation Coefficient}

The Pearson's correlation coefficient " $r$ " is defined as:

$$
r=\frac{N \Sigma x y-(\Sigma x)(\Sigma y)}{\sqrt{ }(N \Sigma x 2-(\Sigma x) 2)(N \Sigma y 2-(\Sigma y) 2)}
$$

(Karl Pearson's correlation formula)

Pearson's Correlation analysis has been used in order to examine the relationship amongst working capital management and profitability. When proficient management of working capital raises profitability of the firm, in that situation we will find a negative affiliation amid the working capital management variables and measures of profitability and vice versa. 
In interpreting the results of Pearson's correlation, one should be awfully careful, since the coefficients results are unable to present a dependable indicator of relationship in a way that organizes meant for supplementary independent variables. Moreover, analysis of easy and uncomplicated bi-variate correlation coefficients under a traditional matrix, do not consider the correlations between each selected variables and entire independent variables (Padachi, 2006). It is for this reasons, our major investigation results will originates from suitable multivariate regression model, which are being estimated using pooled OLS and fixed effect LSDV models.

Results in Table-3 reveal Pearson's correlation analysis among all variables under investigation. It has been found that profitability has an inverse relationship with the debt-equity ratio and debt to total assets ratio. Though cash conversion cycle is negatively related with profitability (ROTA) which is significant at $1 \%$ level, it is positively associated with return on investment which is also significant at $1 \%$ level.

Table 3. Pearson correlations for all variables (10 FMCG firms, 2000-01 to 2009-10: 100 firm-year observations)

\begin{tabular}{|c|c|c|c|c|c|c|c|c|}
\hline & $\mathrm{CCC}_{\mathrm{it}}$ & $\mathrm{DER}_{\mathrm{it}}$ & DTA $_{\text {it }}$ & $\mathrm{AD}_{\mathrm{it}}$ & $\mathrm{AC}_{\mathrm{it}}$ & $\mathrm{AI}_{\mathrm{it}}$ & ROTA $_{i t}$ & $\mathrm{ROI}_{\mathrm{it}}$ \\
\hline $\mathrm{CCC}_{\mathrm{it}}$ & 1 & & & & & & & \\
\hline \multirow[t]{2}{*}{$\mathrm{DER}_{\mathrm{it}}$} & $-.230\left(^{*}\right)$ & 1 & & & & & & \\
\hline & .022 & & & & & & & \\
\hline \multirow[t]{2}{*}{$\mathrm{DTA}_{\text {it }}$} & -.143 & $.867(* *)$ & 1 & & & & & \\
\hline & .156 & .000 & & & & & & \\
\hline \multirow[t]{2}{*}{$\mathrm{AD}_{\mathrm{it}}$} & $.467(* *)$ & -.188 & $-.198(*)$ & 1 & & & & \\
\hline & .000 & .061 & .049 & & & & & \\
\hline \multirow[t]{2}{*}{$\mathrm{AC}_{\mathrm{it}}$} & .074 & $-.204(*)$ & $-.246(*)$ & $.698(* *)$ & 1 & & & \\
\hline & .465 & .042 & .014 & .000 & & & & \\
\hline \multirow[t]{2}{*}{$\mathrm{AI}_{\mathrm{it}}$} & $.830(* *)$ & $-.272(* *)$ & $-.197(*)$ & $.273(* *)$ & $.318(* *)$ & 1 & & \\
\hline & .000 & .006 & .049 & .006 & .001 & & & \\
\hline \multirow[t]{2}{*}{ ROTA $_{\text {it }}$} & $-.288(* *)$ & $-.389(* *)$ & $-.407(* *)$ & $.199\left(^{*}\right)$ & $.224(*)$ & $-.346(* *)$ & 1 & \\
\hline & .004 & .000 & .000 & .047 & .025 & .000 & & \\
\hline \multirow[t]{2}{*}{$\mathrm{ROI}_{\mathrm{it}}$} & $.354(* *)$ & $-.373(* *)$ & $-.388(* *)$ & $.221(*)$ & $.268(* *)$ & $.444(* *)$ & $.914(* *)$ & 1 \\
\hline & .000 & . 000. & .000 & .027 & .007 & .000 & .000 & \\
\hline
\end{tabular}

* Correlation is significant at the 0.05 level (2-tailed).

** Correlation is significant at the 0.01 level (2-tailed).

\subsubsection{Spearman's Correlation Coefficient}

Spearman's rank correlation coefficient or Spearman's rho $(\rho)$, is a non-parametric measure of statistical dependence between two variables. It assesses how well the relationship between two variables can be described using a monotonic function. If there are no repeated data values, a perfect Spearman correlation of +1 or -1 occurs when each of the variables is a perfect monotone function of the other.

A Spearman correlation of 1 result when the two variables being compared are monotonically related, even if their relationship is not linear. In contrast, this does not give a perfect Pearson correlation. When the data are roughly elliptically distributed and there are no prominent outliers, the Spearman correlation and Pearson correlation give similar values. The Spearman correlation is less sensitive than the Pearson correlation to strong outliers that are in the tails of both samples.

Unlike the values given by Pearson's, it is observed that cash conversion cycle is positively related with both the measures of profitability (i.e. ROTA and ROI), and both are significant at $1 \%$ level. 
Table 4. Spearman correlations for all variables (10 FMCG firms, 2000-01 to 2009-10: 100 firm-year observations)

\begin{tabular}{|c|c|c|c|c|c|c|c|c|}
\hline & $\mathrm{CCC}$ & DER & DTA & $\mathrm{AD}$ & $\mathrm{AC}$ & AI & ROTA & ROI \\
\hline CCC & 1.000 & & & & & & & \\
\hline \multirow[t]{2}{*}{ DER } & $-.231\left(^{*}\right)$ & 1.000 & & & & & & \\
\hline & .021 & & & & & & & \\
\hline \multirow[t]{2}{*}{ DTA } & -.069 & $.783(* *)$ & 1.000 & & & & & \\
\hline & .492 & .000 & & & & & & \\
\hline \multirow[t]{2}{*}{$\mathrm{AD}$} & $.440(* *)$ & -.118 & -.111 & 1.000 & & & & \\
\hline & .000 & .243 & .270 & . & & & & \\
\hline \multirow[t]{2}{*}{$\mathrm{AC}$} & .083 & -.145 & $-.211(*)$ & $.683(* *)$ & 1.000 & & & \\
\hline & .414 & .150 & .035 & .000 & . & & & \\
\hline \multirow[t]{2}{*}{ AI } & $.798(* *)$ & $-.318(* *)$ & -.180 & $.260(* *)$ & $.345(* *)$ & 1.000 & & \\
\hline & .000 & .001 & .072 & .009 & .000 & . & & \\
\hline \multirow[t]{2}{*}{ ROTA } & $.344(* *)$ & $-.352(* *)$ & $-.404(* *)$ & $.232(*)$ & $.241(*)$ & $.393(* *)$ & 1.000 & \\
\hline & .000 & .000 & .000 & .020 & .016 & .000 & . & \\
\hline \multirow[t]{2}{*}{ ROI } & $.355(* *)$ & $-.336(* *)$ & $-.374(* *)$ & $.252(*)$ & $.286(* *)$ & $.423(* *)$ & $.940(* *)$ & 1.000 \\
\hline & .000 & .001 & .000 & .012 & .004 & .000 & .000 & \\
\hline
\end{tabular}

* Correlation is significant at the 0.05 level (2-tailed).

** Correlation is significant at the 0.01 level (2-tailed).

\subsection{Regression Statistics}

To examine the influence of working capital management on firms' profitability, the multivariate regressions analysis models i.e. pooled OLS and fixed effect LSDV are expressed in the general form as given in equation 3 and equation 4. Although, these models were applied previously by Deloof (2003), Padachi (2006) and Mathuva (2009) our specified models differ in some ways as mentioned earlier in this study.

Table 5 and table 6 below gives the results of the fixed effects estimations and for the pooled OLS. In all regression models, standard errors are computed by means of White's general heteroscedasticity test. In cases where the White test statistic is statistically significant, heteroscedasticity may not necessarily be the cause, but specification errors. In other words, the White test can be a test of (pure) heteroscedasticity or specification error or both (Gujarati, et. al., 2012). The first half of Table 5 represents the results of regression of ROTA ${ }_{i t}$ applying a fixed effects methodology, where the intercept term is allowed to vary across firms and includes 10 industry dummies. As of our expectation, the firms' profitability as measured by ROTA $\mathrm{it}_{\mathrm{it}}$ increases with decrease in $\mathrm{DTA}_{\mathrm{it}}$, $\mathrm{AD}_{\mathrm{it}}, \mathrm{AC}_{\mathrm{it}}$ and $\mathrm{AI}_{\mathrm{it}}$. Interestingly, $\mathrm{ROTA}_{\mathrm{it}}$ advances with increase in $\mathrm{CCC}_{\mathrm{it}}$. This is contrary to the traditional theory of profitability management where shorter $\mathrm{CCC}_{\mathrm{it}}$ boost up profitability and vice versa. One thing to notice about these results is that all the differential intercept coefficients except $\mathrm{D}_{2 i}$ are individually statistically significant at $1 \%$ and 5\% level, suggesting that the selected FMCG firms are heterogeneous. The results are based on the assumptions that the error term $\varepsilon_{\mathrm{it}} \sim \mathrm{N}\left(0, \sigma^{2}\right)$. Since the index 'i' refer to cross-section observations and ' $\mathrm{t}$ ' to time-series observations, the classical assumption for $\varepsilon_{\mathrm{it}}$ may have to be modified. Under pooled OLS method, ROTA $A_{i t}$ is inversely related with $\mathrm{DER}_{\mathrm{it}}, \mathrm{DTA}_{\mathrm{it}}, \mathrm{AD}_{\mathrm{it}}$ and $\mathrm{AI}_{\mathrm{it}}$, but it is directly related to $\mathrm{CCC}_{\mathrm{it}}$. Coefficient for the constant is high in both the regressions, which indicates that there are other explanatory variables - such as asset management and financing of WC (CL/TA).

It is right away understandable from the $\mathrm{R}^{2}$ and adjusted $\mathrm{R}^{2}$ values that the explanatory power of these models have been improved by using a firm specific intercept. In regression 2 , the $\mathrm{R}^{2}$ and adjusted $\mathrm{R}^{2}$ explain $24.8 \%$ and $19.9 \%$ of the variation in ROTA $_{i t}$ under OLS but within a fixed effects framework the model's explanatory power increases to $47.4 \%$ and $38.0 \%$. The Durbin-Watson value of 1.043 (in regression 1) and 0.891 (in regression 2) indicates the presence of positive serial correlation among the variables though it is slightly lower under fixed effect estimations. 
We have also examined the impact of all explanatory variables on $\mathrm{ROI}_{\mathrm{it}}$ the results of which are given in table 6 . It has been observed that with one unit increase in $\mathrm{CCC}_{\mathrm{it}}, \mathrm{DTA}_{\mathrm{it}}$ and $\mathrm{AC}_{\mathrm{it}}$, the profitability of the firms decrease by 0.581 units, 10.408 units and 1.007 units under fixed effect LSDV model. These findings indicate that both cash conversion cycle and debt used by the firm are negatively associated with firm's profitability. But, pooled OLS method shows that when $\mathrm{DER}_{\mathrm{it}}, \mathrm{DTA}_{\mathrm{it}}, \mathrm{AD}_{\mathrm{it}}$ and $\mathrm{AI}_{\mathrm{it}}$ increases by one unit, $\mathrm{ROI}_{\mathrm{it}}$ of the selected firms decrease by 0.262 units, 22.812 units, 0.821 units and 0.274 units.

The multiple correlation coefficient between the dependent variable $\mathrm{ROI}_{\mathrm{it}}$ and the independent variables taken together is found be 0.803 under fixed effect estimations, which is much higher than the correlation coefficient value of 0.545 obtained under pooled OLS. It signifies that the profitability is highly responded by its working capital management indicators under fixed effect LSDV than under pooled OLS. It is also evident from the value of $\mathrm{R}^{2}$ that 64.4 per cent of variation in $\mathrm{ROI}_{\mathrm{it}}$ is accounted by the joint variation of all explanatory variables taken together under fixed effect model. But, applying pooled OLS the value of $\mathrm{R}^{2}$ is only 29.7 per cent. These results certainly prove the better acceptance of fixed effect LSDV model than pooled OLS.

Table 5. Regressions of ROTA on working capital variables (10 FMCG firms, 2000-01 to 2009-10: 100 firm-year observations)

\begin{tabular}{|c|c|c|c|c|c|c|c|c|}
\hline \multicolumn{9}{|c|}{ Equation 4: Dependent Variable - ROTA $_{\text {it }}$} \\
\hline \multirow[t]{3}{*}{ Regression Model: } & \multirow{2}{*}{\multicolumn{4}{|c|}{$\begin{array}{l}\text { Fixed Effect LSDV } \\
\text { (1) }\end{array}$}} & \multirow{2}{*}{\multicolumn{4}{|c|}{$\begin{array}{l}\text { Pooled OLS } \\
\text { (2) }\end{array}$}} \\
\hline & & & & & & & & \\
\hline & Coefficient & $\mathrm{t}$ & Sig. & tolerance & Coefficient & $\mathrm{t}$ & Sig. & tolerance \\
\hline Constant & 9.468 & 1.490 & .140 & - & 9.820 & 1.792 & .076 & - \\
\hline $\mathrm{CCC}_{\mathrm{it}}$ & .229 & .160 & .873 & .003 & 1.127 & .726 & .470 & .003 \\
\hline $\mathrm{DER}_{\mathrm{it}}$ & 3.248 & .504 & .616 & .144 & -1.174 & -.205 & .838 & .236 \\
\hline DTA $_{\text {it }}$ & -10.146 & -1.049 & .297 & .180 & -15.637 & -1.644 & .104 & .240 \\
\hline $\mathrm{AD}_{\mathrm{it}}$ & -.089 & -.063 & .950 & .005 & -1.074 & -.691 & .491 & .005 \\
\hline $\mathrm{AC}_{\mathrm{it}}$ & -.088 & -.061 & .951 & .005 & 1.168 & .749 & .456 & .005 \\
\hline $\mathrm{AI}_{\mathrm{it}}$ & -.266 & -.188 & .851 & .003 & -.847 & -.552 & .582 & .004 \\
\hline $\mathrm{D}_{2 \mathrm{i}}$ & 5.598 & 1.229 & .223 & .378 & - & - & - & - \\
\hline $\mathrm{D}_{3 \mathrm{i}}$ & 18.977 & 3.450 & .001 & .259 & - & - & - & - \\
\hline $\mathrm{D}_{4 \mathrm{i}}$ & 9.249 & 1.955 & .054 & .351 & - & - & - & - \\
\hline $\mathrm{D}_{5 \mathrm{i}}$ & 11.945 & 2.903 & .005 & .464 & - & - & - & - \\
\hline $\mathrm{D}_{6 \mathrm{i}}$ & 13.990 & 3.143 & .002 & .396 & - & - & - & - \\
\hline $\mathrm{D}_{7 \mathrm{i}}$ & 24.032 & 4.710 & .000 & .301 & - & - & - & - \\
\hline $\mathrm{D}_{8 \mathrm{i}}$ & 26.490 & 4.805 & .000 & .258 & - & - & - & - \\
\hline $\mathrm{D}_{9 \mathrm{i}}$ & 12.986 & 2.792 & .006 & .363 & - & - & - & - \\
\hline $\mathrm{D}_{10 \mathrm{i}}$ & 18.890 & 3.902 & .000 & .335 & - & - & - & - \\
\hline $\mathrm{R}$ & \multicolumn{4}{|c|}{0.688} & \multicolumn{4}{|c|}{0.497} \\
\hline $\mathrm{R}^{2}$ & \multicolumn{4}{|c|}{0.474} & \multicolumn{4}{|c|}{0.248} \\
\hline Adjusted $\mathrm{R}^{2}$ & \multicolumn{4}{|c|}{0.380} & \multicolumn{4}{|c|}{0.199} \\
\hline SEE & \multicolumn{4}{|c|}{8.40418} & \multicolumn{4}{|c|}{9.55095} \\
\hline Durbin-Watson & \multicolumn{4}{|c|}{1.043} & \multicolumn{4}{|c|}{0.891} \\
\hline
\end{tabular}


Table 6. Regressions of ROI on working capital variables (10 FMCG firms, 2000-01 to 2009-10: 100 firm-year observations)

\begin{tabular}{|c|c|c|c|c|c|c|c|c|}
\hline \multicolumn{9}{|c|}{ Equation 4: Dependent Variable - $\mathrm{ROI}_{\text {it }}$} \\
\hline \multirow{3}{*}{$\begin{array}{l}\text { Regression } \\
\text { Model: }\end{array}$} & \multirow{2}{*}{\multicolumn{4}{|c|}{$\begin{array}{l}\text { Fixed Effect LSDV } \\
\text { (1) }\end{array}$}} & \multirow{2}{*}{\multicolumn{4}{|c|}{$\begin{array}{l}\text { Pooled OLS } \\
\text { (2) }\end{array}$}} \\
\hline & & & & & & & & \\
\hline & Coefficient & $\mathrm{t}$ & Sig. & tolerance & Coefficient & $\mathrm{t}$ & Sig. & tolerance \\
\hline Constant & 11.295 & 1.418 & .160 & - & 5.078 & .629 & .531 & - \\
\hline $\mathrm{CCC}_{\mathrm{it}}$ & -.581 & -.324 & .746 & .003 & .854 & .374 & .710 & .003 \\
\hline $\mathrm{DER}_{\mathrm{it}}$ & 1.720 & .213 & .832 & .144 & -.262 & -.031 & .975 & .236 \\
\hline DTA $_{i t}$ & -10.408 & -.859 & .393 & .180 & -22.812 & -1.628 & .107 & .240 \\
\hline $\mathrm{AD}_{\mathrm{it}}$ & .774 & .435 & .665 & .005 & -.821 & -.359 & .721 & .005 \\
\hline $\mathrm{AC}_{\mathrm{it}}$ & -1.007 & -.560 & .577 & .005 & .991 & .431 & .667 & .005 \\
\hline $\mathrm{AI}_{\mathrm{it}}$ & .508 & .287 & .775 & .003 & -.274 & -.121 & .904 & .004 \\
\hline $\mathrm{D}_{2 \mathrm{i}}$ & 8.777 & 1.537 & .128 & .378 & - & - & - & - \\
\hline $\mathrm{D}_{3 \mathrm{i}}$ & 27.536 & 3.993 & .000 & .259 & - & - & - & - \\
\hline $\mathrm{D}_{4 \mathrm{i}}$ & 9.203 & 1.552 & .124 & .351 & - & - & - & - \\
\hline $\mathrm{D}_{5 \mathrm{i}}$ & 17.779 & 3.447 & .001 & .464 & - & - & - & - \\
\hline $\mathrm{D}_{6 \mathrm{i}}$ & 17.228 & 3.088 & .003 & .396 & - & - & - & - \\
\hline $\mathrm{D}_{7 \mathrm{i}}$ & 45.422 & 7.103 & .000 & .301 & - & - & - & - \\
\hline $\mathrm{D}_{8 \mathrm{i}}$ & 41.829 & 6.053 & .000 & .258 & - & - & - & - \\
\hline $\mathrm{D}_{9 \mathrm{i}}$ & 15.769 & 2.705 & .008 & .363 & - & - & - & - \\
\hline $\mathrm{D}_{10 \mathrm{i}}$ & 25.038 & 4.126 & .000 & .335 & - & - & - & - \\
\hline $\mathrm{R}$ & \multicolumn{4}{|c|}{0.803} & \multicolumn{4}{|c|}{0.545} \\
\hline $\mathrm{R}^{2}$ & \multicolumn{4}{|c|}{0.644} & \multicolumn{4}{|c|}{0.297} \\
\hline Adjusted $\mathrm{R}^{2}$ & \multicolumn{4}{|c|}{0.581} & \multicolumn{4}{|c|}{0.252} \\
\hline SEE & \multicolumn{4}{|c|}{10.53417} & \multicolumn{4}{|c|}{14.06731} \\
\hline Durbin-Watson & \multicolumn{4}{|c|}{1.028} & \multicolumn{4}{|c|}{0.799} \\
\hline
\end{tabular}

\section{Conclusions}

The necessity of firms' working capital alters over time like its internal cash generation rate and thus FMCG firms should sustain a good harmonization of its assets and liabilities. In this connection, our study have recognized significant management practices which is expected to help out finance managers and practitioners to recognize vital areas which might improve the financial performance of their firm's operation.

In this study, we empirically investigated the effect of working capital management on firm's profitability as measured by return on total assets and return on investment using a sample of Indian FMCG companies. For this purpose we have employed two models of panel data regression analysis - fixed effect LSDV and pooled OLS model. As mentioned earlier, the results of our study indicate the better explanatory power of fixed effect LSDV model than that of pooled OLS model. Furthermore, in this model the heterogeneity or individual characteristics of each selected FMCG firms have been taken into account.

The findings of our study results under fixed effect estimations demonstrate that $\mathrm{DTA}_{\mathrm{it}}, \mathrm{AD}_{\mathrm{it}}, \mathrm{AC}_{\mathrm{it}}$, and $\mathrm{AI}_{\mathrm{it}}$ are negatively associated with firm's profitability as quantified by ROTA $\mathrm{i}_{\mathrm{it}}$. Again, when we assess the impact of all explanatory variables on $\mathrm{ROI}_{\mathrm{it}}$, we found that $\mathrm{CCC}_{\mathrm{it}}, \mathrm{DTA}_{\mathrm{it}}$ and $\mathrm{AC}_{\mathrm{it}}$ are negatively associated with $\mathrm{ROI}_{\mathrm{it}}$. Thus, the results of our study are in line with the findings of Deloof (2003) and Padachi (2006), who found a strong negative relationship between the measures of working capital management with corporate profitability using fixed effect model. Hence, the findings of our study highlights the importance of proficient working capital management to ensure an improvement in firm's profitability and this aspect must form part of the company's 
strategic and operational thinking in order to operate effectively and efficiently in India's new challenging economic environment.

\section{Acknowledgement}

Authors are grateful to Basanta Khamrui, Assistant Professor, Department of Commerce, Gour Mohan Roy College, Monteswar, Burdwan, India, for his sincere cooperation in collection of data from CMIE.

\section{References}

Agarwal, J. D. (1988). A goal programming model for working capital management. Finance India, 2(2), 49-61. Bagchi, B., \& Khamrui, K. (2012). Relationship between working capital management and profitability: a study of selected FMCG companies in India. Business and Economics Journal, 2012, 1-11.

Bhunia A. (2010). A study of managing liquidity. Journal of Management Research, 1(9), 21. http://dx.doi.org./1941899X/20110701

Ching, H. Y., Novazzi, A., \& Gerab, F. (2011). Relationship between working capital management and profitability in Brazilian listed companies. Journal of Global Business and Economics, 3, 74-86.

Christopher, S. B., \& Kamalavalli, A. L. (2009). Sensitivity of profitability to working capital management in Indian corporate hospitals. Retrieved from http://ssrn.com/abstract $=1331500$

Deloof M., \& Jegers, M. (1996). Trade credit, product quality, and intra group trade: some European evidence. Financial Management, 25, 33-43. http://dx.doi.org/10.2307/3665806

Deloof, M. (2003). Does working capital management affect profitability of Belgian firms? Journal of Business Finance \& Accounting, 30, 573-587. http://dx.doi.org/10.1111/1468-5957.00008

Eljelly, A. (2004). Liquidity-profitability tradeoff: an empirical investigation in an emerging market. International Journal of Commerce \& Management, 14, 48-61. http://dx.doi.org/10.1108/10569210480000179

Ganesan, V. (2007). An analysis of working capital management efficiency in telecommunication equipment. Industryrivier Academic Journal, 3(2), Fall.

Garcia-Teruel, P. J., \& Martinez-Solano, P. (2007). Effects of working capital management on SME profitability. International Journal of Managerial Finance, 3(2), 35-51. http://dx.doi.org/10.1108/17439130710738718

Gujarati, D. N., Porter, D. C., \& Gunasekar, S. (2012). Basic econometrics (5th ed.). New Delhi: McGraw-Hill, 625-638.

Lazaridis I., \& Tryfonidis, D. (2006). Relationship between working capital management and profitability of listed companies in the Athens stock exchange. Journal of Financial Management and Analysis, 19(1), 26-35.

Lee, A. H. I., \& Kang, H. Y. (2008). A mixed 0-1 integer programming for inventory model: A case study of TFT-LCD manufacturing company in Taiwan. Kybernetes, 37(1), 58-76. http://dx.doi.org/10.1108/03684920810850998

Long, M. S., Malitz, L. B., \& Ravid, S. A. (1993). Trade credit, quality guarantees, and product marketability. Financial Management, 22, 117-127. http://dx.doi.org/10.2307/3665582

Mathuva, D. (2009). The influence of working capital management components on corporate profitability: a survey on Kenyan listed firms. Research Journal of Business Management, 3, 1-11.

Norušis, M. J. (1993). SPSS for Windows Base System Users Guide: Release 6.0. Englewood Cliffs: Prentice Hall.

Padachi, K. (2006). Trends in working capital management and its impact on firms' performance: an analysis of Mauritian small manufacturing firms. International Review of Business Research Papers, 2, 45-58.

Raheman, A., \& Nasr, M. (2007). Working capital management and profitability - case of Pakistani firms. International Review of Business Research Papers, 3, 279-300.

Shin, H. H., \& Soenen, L. (1998). Efficiency of working capital and corporate profitability. Financial Practice and Education, 8(2), 37-45.

Uyar, A. (2009). The relationship of cash conversion cycle with firm size and profitability: an empirical investigation in Turkey. International Research Journal of Finance and Economics, 24. 